УДК 94 (477)(094) «1941»

ТРОФИМОВИЧ В.В.

http://orcid.org/0000-0003-0083-0437

ТРОФИМОВИЧ Л.В.

http://orcid.org/0000-0003-2393-9128

https://doi.org/10.33577/2313-5603.31.2019.81-98

\title{
ВІДОБРАЖЕННЯ АКТА 30 ЧЕРВНЯ 1941 РОКУ В ІСТОРИЧНИХ ПРАЦЯХ І МЕМУ АРАХ УЧАСНИКІВ УКРАЇНСЬКОГО ВИЗВОЛЬНОГО РУХУ
}

У статті здійснена спроба охарактеризувати Акт відновлення української державності через призму історичних праць і мемуарів учасників визвольного руху. 3'ясована тогочасна діяльність ОУН(б) та їі взаємини 3 німецькими окупантами. Звернута увага на те, що її лідери до липня 1941 р. мали переважно слабке уявлення про справжні плани нацистської верхівки стосовно України. Наведені факти широкої підтримки українцями Акта 30 червня 1941 р. та їхньої активної участі у державотворчому процесі. Висвітлена реакція німецького керівництва на Акт 30 червня і наступні дії ОУН(б). Вказано на закінчення ситуативного союзу між гітлерівцями й бандерівцями і початок підготовки останніх до відкриття антинімецького фронту.

Ключові слова: Акт 30 червня 1941 р., відновлення української державності, ОУН(б), німці, праці, мемуари.

Постановка проблеми та ї̈ актуальність. Майже вісім десятиріч відділяє нас від безкомпромісного Акта відновлення української державності. «Актом 30 червня 1941 р., - писав Петро Мірчук, український нарід заманіфестував перед цілим світом і перед історією, що він бажає сам керувати своїм життям і що він готов боронити своє право на вільне життя у своїй власній, самостійній державі перед імперіалістичними зазіханнями кожного ворога і за кожних умов... Акт відновлення української державності та успішна політична й мілітарна боротьба проти німецького окупанта $є$ доказом політичної зрілості, моральної сили та здисциплінованості українського народу і ввійдуть в історію як світла сторінка гідної постави української нації в важких умовинах Другої світової війни» (Мірчук, 1953:52, 56).

Трофимович Володимир Васильович, доктор історичних наук, професор, професор кафедри гуманітарних наук, Національна академія сухопутних військ імені гетьмана Петра Сагайдачного, м. Львів.

Трофимович Лілія Володимирівна, кандидат історичних наук, доцент, доцент кафедри гуманітарних наук, Національна академія сухопутних військ імені гетьмана Петра Сагайдачного, м. Львів.

(C) Трофимович В.В., Трофимович Л.В., 2019 
Аналіз попередніх досліджень. Унікальне джерело вивчення передумов, причин і наслідків проголошення Акта становлять твори та мемуари учасників українського визвольного руху. Уміщуючи значну кількість фактичного матеріалу, насичені враженнями та спостереженнями, вони значною мірою дають змогу відтворити тогочасні події, проаналізувати позицію керманичів ОУН, показати їх взаємини з нацистами. Водночас, віддаючи належне значущості вищевказаним джерелам, ми враховували притаманну їм істотну дозу авторського суб'єктивізму, можливість відхилення при висвітленні описуваних подій, що пов'язано з обмеженістю людської пам'яті, а тому викладений тут матеріал зіставлявся зі свідченнями інших джерел.

Мета та завдання дослідження. Спираючись на твори та мемуари учасників української визвольної боротьби періоду Другої світової війни, здійснена спроба простежити відображення у них передумов, причин і наслідків Акта 30 червня 1941 р.

Виклад основного матеріалу дослідження. Напередодні нападу Німеччини на СРСР ОУН(б) і ОУН(м) істотно пожвавили свою діяльність. «Про те, що буде війна, знав кожний смертельник, іiі було чути в весняному повітрі, - згадував Максим Скорупський. ... Українці готувались до війни. Організації УН - Мельника i Бандери - в великій тайні перед німцями транспортували людей на землі й масово перекидали своїх членів на терен т. зв. Г.Г.» (Tyдu, де бій за волю, 1992:49).

Як випливає 3 праць і мемуарів оунівських лідерів, керуючись постулатом «опертя на власні сили» як засадничий фундамент в їхній боротьбі за українську державність, вони разом із тим не виключали можливої підтримки ззовні. 3 цього приводу Микола Лебедь писав: «У тій площині тодішнє українство та його політичний провід шукали в світі прихильників чи там союзників, які були б готові дати бодай моральну підтримку українському народові в реалізації його цілей. Був факт, що в сучасній Європі тільки Німеччина явно готувалася до війни з СРСР, і тому це було природне й наскрізь зрозуміле явище, що український нарід сподівався від німецько-совєтського конфлікту зміни дотеперішнього положення, але очевидячки не такої, щоб поневолення большевицькою Москвою замінити новим поневоленням Німеччиною. Бо сподіваючись німецько-совєтської війни, український нарід підготовлявся використати iї виключно для того, щоб відбудувати свою самостійну незалежну державу» (Лебедь, 1946:13). 
Опрацювання теоретичної та мемуарної спадщини оунівських функціонерів наводить на думку, що на початку війни останні мали переважно слабке уявлення про нацистські наміри стосовно України. «Питання, як поведуться німці супроти України, залишалось відкритим, - згадував член Проводу українських націоналістів Дмитро Андрієвський. - Щоб вияснити позицію німців, ПУН уважав за вказане викликати їх на одвертість і 3 тією метою в квітні 1941 р. зложив записку, в якій виложив національнодержавницькі позиції ОУН... Співробітник Референта Зовнішніх Справ, д-р Панченко-Юревич, що був головним автором записки, передав іiі в належні руки. Сподіваної реакції в написаній формі не було...» (Андрієвський, 1955:156).

Водночас, доки офіційний Берлін не продемонстрував неприхованої ворожнечі до України, доти міркування очільників бандерівської ОУН полягали у наступному. Якщо він поставить за мету розвалити СРСР на національні незалежні держави, зазначав Ярослав Стецько, то ОУН буде вважати Німеччину зовнішньо-політичним союзником проти сталінського режиму (Стецько, 1967:193). Своєю чергою, Степан Бандера наголошував, що ...українцям, на його думку, в умовах, що склалися після 22 червня 1941 р., належало безкомпромісно плекати свою долю власними руками. Виходячи 3 цього, тогочасне ставлення Організації до офіційного Берліна уявлялося таким: доконані факти з ймовірною перспективою співробітництва на засадах рівноправності та реалізація доконаних фактів на випадок іншого розвитку подій (Бандера, 1948:15). «3 цією нашою тактикою вичікування, - пояснював Я. Стецько, - не стоїть у ніякому зв'язку рішення проголосити відновлення державности і творити державне правління, бо це не було залежне від тієї чи іншої постави Німеччини, але це була закономірна консеквенція боротьби нації за незалежність, яка використовує кожну міжнародну пригожу ситуацію, щоб задокументувати свою волю до державного незалежного життя» (Стецько, 1967:29).

Характерно, що ще у Меморандумі, підготовленому групою членів РП ОУН на чолі зі С. Бандерою за тиждень до початку німецькорадянської війни та переданому до Райхсканцелярії 23 червня, звучало недвозначне попередження i навіть прихована погроза на адресу офіційного Берліна: «Навіть, якщо німецькі війська при вступі в Україну, звичайно, спочатку будуть вітати як визволителів, то незабаром ця ситуація може змінитися, якщо Німеччина прийде в 
Україну не 3 метою відновлення Української держави і відповідними гаслами» (ОУН в 1941 рощі. Ч. 1, 2006:183). І далі: «Українець також, яким його створили останні двадцять років, повний рішучості створити підвалини, які б забезпечили національний розвиток в незалежній державі. 3 цією рішучістю повинна рахуватися кожна держава, яка, переслідуючи власні інтереси, хоче створити новий порядок на східноєвропейському просторі» (ОУН в 1941 роціi. Ч. 1, 2006:188).

Отже, твори та мемуари керманичів бандерівської ОУН підтверджують думку про те, що Організація була категорично налаштована на відновлення державності.

Разом $з$ тим, як зазначив Ярослав Дашкевич, в оунівському середовищі плекалася романтична мрія, що розпочата війна буде стимулом до чергової української революції, яка розв'яже державотворчі та інші завдання. «Неадекватне захоплення міфом Української революції 1917 - 1921 рр., всі помилки якої треба було виправити, стало причиною цієї ілюзії. Війна 1941 р. революційної ситуації на стероризованій і безмежно заляканій Східній Україні не створила, а революційні прояви на західноукраїнських землях, які спостерігалися в червні-липні 1941 р., майже зразу опинилися під контролем нових окупантів, або були придушені кованим німецьким чоботом. Реальна дійсність виявилася далекою від пророкованого сценарію» (Дашкевич, 2001:XLIII).

Для здійснення запланованого, як писав Василь Кук, поряд 3 трьома Похідними групами сформовано спеціальну - Львівську (близько 20 осіб), до складу якої увійшли члени Проводу ОУН(б) та іiі ключові функціонери. Вона мала вирішувати завдання, пов’язані 3 відновленням державності. 23 червня В. Кук, М. Лебедь, I. Равлик, Я. Стецько на автомобілі прибули на правий берег р. Сян 3 метою найшвидше потрапити до Львова (Кук, 2001:XI-XIII). «3 Кракова виїхали ми таємно від німців, використовуючи наявні в нас німецькі військові документи, - писав В. Кук. - Добратись нам до Львова треба було раніше, ніж там установиться німецька адміністрація. Цим пояснюється поспіх групи: якнайшвидше до Львова, щоб не запізнитись! ... 28 червня ... в’їхали ми у Львів» (Кук, 2001:XI-XII).

За спогадами В. Кука, він одразу зайнявся встановлюванням зв'язків із українським підпіллям, відновленням і водночас перебудовою роботи бандерівської ОУН: «Доки німці не визначили 
свого ставлення до української державності, необхідно було зберегти підпільну мережу, робити запаси зброї й амуніції, медикаментів та підпільної техніки. 3 іншого ж боку, треба було також частину кадрів скерувати на роботу в легальних установах (державно-адміністративних, культурно-освітніх тощо). Іван Равлик та Свген Врецьона із запалом узялися за організацію у Львові місцевої української міліції, яка у той час стала єдиною реальною силою, на котру могла легально опертися новостворювана українська влада» (Кук, 2001:XIII).

Інші члени Львівської групи 29 і 30 червня здійснювали інтенсивну підготовку до скликання Народних Зборів. Зокрема, Я. Стецько мав зустрічі із відомими громадськими діячами міста 3 метою запрошення на них останніх, а також обговорював їх входження до уряду, що формувався, і до міської управи (Кук, 2001:XII).

Уранці 30 червня гітлерівські військові частини увійшли у Львів. «Львів прийняв німців 3 мішаними почуваннями, - писав у своїх мемуарах Кость Паньківський. - Не було того ентузіазму, 3 яким вітали в 1915 році австрійців після російської інвазії, але була велика радість 3 приводу відходу більшовиків. Неповні два роки їх панування далися добре взнаки, що ж сказати про останній тиждень війни й терору» (Паньківський, 1957:30).

Серед прибулих вояків був і батальйон «Нахтігаль», український особовий склад якого ще майже два тижні перед тим присягнув на вірність українському народові. «Українське населення дуже врадувалося, бачачи в місті рідне військо, - згадував Степан Котелець-Лісовий. - Вістка про це дуже швидко поширилася по всій околиці, і відразу з усіх сусідніх сіл і містечок почали до Львова масово приїздити, здебільше на роверах, хлопці і дівчата, щоб зустрітися зі своїми братами або судженими в рядах нашого війська. Це були дуже радісні хвилини вітання, з обіймами, поцілунками, сльозами зворушення ... молодих хлопців найбільше цікавило питання, коли почнуть брати їх усіх до українського війська» (Котелеиь-Лісовий, 1982:81).

Слід зазначити, що з ініціативи ОУН(б) 22 червня у Кракові був створений Український Національний Комітет, до складу якого увійшли особи, які представляли більшість емігрантських організацій (Лебедь, 1946:14).

Зміст праць і спогадів оунівських діячів засвідчив: заява фюрера 22 червня 3 приводу нападу на СРСР, нестримний рух гітлерівських військ углиб України, їх відверте ігнорування перемовин 3 
бандерівцями штовхало останніх до відповідних висновків. Їм ставало все більш очевидно, що очільники Третього райху, поперше, не виявляють бажання підтримати державотворчі процеси в Україні, а по-друге, не насміляться на перших порах викликати проти себе спротив іiї народу. Двоїстою політикою, пустопорожніми обіцянками, підігріванням сподівань на державну незалежність після переможної війни з Радянським Союзом вони намагалися перешкодити тому, аби рух українців до незалежності був націлений проти райху. Натомість, офіційний Берлін прагнув залучити останніх у війну проти СРСР, міцно пов'язати 3 нацистськими намірами, не допустити здійснення ними самостійної політики, використати сповна і виснажити сили українського народу, реалізовувати власні плани, згідно з якими Україна мала стати колонією. Як бачимо, бандерівці не мали жодних аргументів на користь того, що нацисти зацікавлені у відродженні української державності і, крім того, дозволять здійснити цей акт у Києві. Лідери ОУН(б) тепер схилялися до думки, що самостійна політика повинна здійснюватися за власною ініціативою. Йшлося про те, щоб скористатися тогочасним хаосом і безладдям, коли радянські війська залишили Львів, а наступаючі гітлерівські ще не встигли створити постійну адміністрацію, і невідкладно проголосити відновлення Української держави.

Отже, ОУН(б) прагнула радикальними діями поставити нацистів перед доконаним фактом, змусити їх вже тоді чітко визначитися: підтримувати чи не підтримувати українські державотворчі кроки, створити юридичну основу для наступних державотворчих процесів чи боротьби $з$ тими, хто стане на перешкоді реалізації цих планів, перекреслити найнебезпечніші для України підступні гітлерівські задуми і відкрити перспективу незалежній визвольній політиці.

Слід зазначити, що контури майбутнього Акта проглядалися вже у травневих 1941 р. політичних вказівках ОУН(б) «Боротьба й діяльність ОУН під час війни» та в загальних напрямних з інструкцій iї Революційного Проводу під аналогічною назвою. Тут, зокрема стверджувалося: «На звільнених від московсько-большевицької окупації частинах української землі, не ждучи на ніщо, ОУН проголошує відбудову Української держави, встановляє владу, яка має зорганізувати державне життя в усіх ділянках та кермувати ним... Центром краєвої влади повинен бути Львів». Автори цих документів водночас попереджали: якщо з боку нацистів буде негативна реакція на призначення оунівських представників в органи управління і спроби заміни останніх своїми людьми, то не підкорятись 
німецьким наказам, мотивуючи це тим, що тільки керівництво ОУН(б) може усунути їх 3 посад (ОУН в 1941 pou̧i, 4. 1, 2006:61, 68, 71).

Як випливає зі спогадів Юрія Степового, «ОУН ще на самому початку німецького маршу на Схід стояла на засаді, що німцям не можна довіряти в їхніх обіцянках, але, по можливості, пролазити до їхніх установ і під плащиком лояльності та співпраці розбудовувати якнайширше революційне підпілля, на кожному кроці саботувати їхні наміри...»(Степовий, 1947:12). Інший оунівець, М. Карпій, згадував, що за кілька днів до скликання Народних Зборів він отримав від керівника Похідної групи «Північ» Дмитра Мирона розпорядження про те, що якщо німці вороже зустрінуть проголошення відновлення державності на Тернопільщині, то потрібно буде «стріляти їх» (Kapniü, 1943:23).

Звідси можна зрозуміти, що львівський сценарій задумувався бандерівцями заздалегідь, у глибокій таємниці від гітлерівців, тим більше без погодження $з$ ними, і через це став для останніх цілковитою несподіванкою.

Тим часом 30 червня понад 60 осіб заповнили приміщення Товариства «Просвіта». «Тут зібрались, - зазначив В. Кук, - представники української громадськості Львова й околиць: церковні достойники, вчені, інтелігенція, робітники, селяни, учасники підпільної визвольної боротьби» (Кук, 1993:31).

Звертаючись до них, Я. Стецько озвучив Акт відновлення Української Держави. В ньому зазначалося, що «волею українського народу Організація Українських Націоналістів під проводом Степана Бандери проголошує відновлення Української Держави, за яку поклали свої голови цілі покоління найкращих синів України» (ОУН в 1941 роųi. Ч. 1, 2006:250-251).

До речі, ця думка вказувала також на зв'язок української державності 1917 - 1921 рр. $з$ тогочасним державотворчим процесом. Тут же повідомлялося, що на західноукраїнських землях формується українська влада, яка підпорядкується загальнонаціональному уряду, створеному у Києві з волі українського народу.

Звертаємо увагу на те, що структурно текст проголошеного документа складався 3 трьох пунктів. Окрім вищевикладених двох, останній у післявоєнних виданнях на Заході переважно опускався, що давало привід опонентам називати бандерівців «маріонетками», «колаборантами», а сам Акт - «оперетковим». А лакуни в тексті 
звучали так: «3. Відновлена Українська держава буде тісно співдіяти з націонал-соціалістичною Велико-Німеччиною, що під проводом Адольфа Гітлера творить новий лад в Європі й світі та допомагає українському народові визволитися 3-під московської окупації. Українська Національна Революційна Армія, що творитиметься на українській землі, боротиметься дальше спільно з союзною німецькою армією проти московської окупації за Суверенну Соборну Українську Державу і новий лад у цілому світі» (OУH в 1941 рочі. Ч. 1, 2006:251).

3 цього приводу В. Кук писав так: «Кожна політично грамотна людина, вникнувши у зміст цього абзацу, може зробити лише один висновок: новоповстаюча Українська Держава буде співпрацювати 3 Німеччиною тільки за умови визнання німецьким урядом Української держави. Для того й проголошувалась Українська держава, власне створювався уряд, щоб Україна могла на рівних правах вести переговори, укладаючи союзи, провадити спільну війну проти своїх національних ворогів. Це цілком нормальна політика вільного суверенного народу» (Кук, 2001:XIX). Він пояснював, що оунівці не робили секрету 3 того, що вбачали у Третьому райху союзника у війні з СРСР, але лише у випадку визнання Берліном української державності. У зв'язку з цим для них не мав жодного значення характер політичного ладу в Німеччині, оскільки визначальним була протидія спільному ворогу. Адже США та Великобританія також закрили очі на сталінський тоталітарний режим, коли об'єдналися з ним в коаліцію проти теж спільного ворога нацизму (Кук, 2001:XIX).

Своє тлумачення змісту третього пункту виклав і С. Бандера у зверненні «Слово до Українських Націоналістів-Революціонерів за кордоном» від 1948 р. «Дехто закидає, що під час Акта 30 червня 1941 р. були вжиті фрази і жести приязного супроти Німеччини тону, - писав він. - В цій справі пора сказати отверте слово, бо наша правда ясна і чиста, і треба припинити фальшиве змалювання дійсности... Коли ж Німеччина пішла війною проти Росії, нашого ворога, то Україна не могла прийняти неприхильно цього факту. Але тим ще не розв'язувалося питання взаємин між Україною i Німеччиною. Воно мусіло залежати тільки від одного: як поставиться Німеччина до державної суверенности України, чи буде шанувати українську суверенність, українські інтереси, чи буде шукати в Україні союзника проти большевицької Росії, - чи трактуватиме 
Україну як воєнну здобич і об’єкт своїх цілей... Ми мусіли стати і стали на позиції незалежної реалізації наших національних цілей, оборони наших прав і інтересів. А далі мусіла сказати своє слово Німеччина» (Бандера, 1948:17). На зборах було зачитано декрет про створення Державного Правління, очолювати яке призначили Я. Стецька. Хоча про їх скликання німецьку адміністрацію не поставили до відома, у залі з'явилися капітан Ганс Кох - колишній сотник Української Галицької Армії і майор Еріх фон Айкерн. Попросивши слова, Г. Кох зробив акцент на тому, що в умовах війни потрібно сконцентрувати всі сили для остаточної перемоги над більшовицьким ворогом, а тому українська справа не на часі. Тим більше що вона не відноситься до повноважень вермахту, а у майбутньому іï буде розв'язувати сам фюрер. «У промові Коха була помітна нервозність, невпевненість, - пригадував В. Кук. Видно було, що і скликання Народних Зборів, і проголошення Акта відновлення Української Держави було для німців цілковитою і дуже неприємною несподіванкою. Всі присутні в залі 3 його виступу зрозуміли (до речі, Г. Кох виголосив промову спочатку

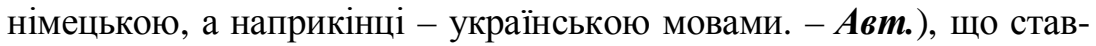
лення німецького уряду до української державності буде негативне, але мовчали» (Кук, 1993:47).

У розглядуваний період стало відомо, що напередодні відступу радянських військ органи НКВС масово знищували у тюрмах політв'язнів. «Я досі не можу спокійно згадувати страшних картин, які довелося побачити в перші дні війни, - писала пізніше член ОУН Галина Дідик. - Тоді, після відступу радянських військ, розшукуючи близьких мені людей, я була в тюрмах Львова, Тернополя, Бережан, Нараєва. Я бачила витягнені з катівень і потаємних ям і виставлені для опізнання рідними і друзями тисячі трупів постріляних, помордованих, часом із слідами варварських знущань: вирізаними на тілі тризубами, виколотими очима, повідрізуваними носами, вухами, грудьми» (Дідик, 1987:188). Враження про ці жахіття знаходимо і в мемуарах учасниці оунівського підпілля Марії Савчин. «Напередодні втечі НКВД масово вимордувала українських політв'язнів у львівських тюрмах, - згадувала вона. - Тюремні підвали, подвір'я і камери були загачені трупами помордованих. Туди приходили рідні та впізнавали серед убитих своїх дітей, батьків. Скоро стало відомо, що таке ж вимордування політв'язнів було проведене по всіх містах Західної України. На честь загиблих 
ОУН(p) встановила загальну жалобу, і в пам'ять про них насипали по селах і містах високі могили. Вони, ті могили, постійно нагадували нам, що боротьба, в якій віддали життя помордовані в'язні, ще не закінчена і на нас лягає обов'язок завершити іiі перемогою» (Савчин, 2003:40-41).

У зв'язку з тим для значної частини краян гітлерівці сприймалися рятівниками від злочинів радянського режиму, а учасники зборів із розумінням сприйняли останній пункт Акта.

Інформація про Акт відновлення української державності швидко поширювалась українськими теренами, викликаючи урочисті демонстрації, підписання численних маніфестів на його підтримку, що, до речі, підтверджувало легітимність останнього. У таких умовах оунівці приступили до формування місцевих державних адміністрацій. «Війна принесла синьо-жовті прапори на Україну в неможливо короткий строк, - писав Тарас Клекіт у статті «Голос крови», надрукованій у підпільному журналі ОУН «Ідея і чин». - Їм не здивувалися, не запитували, чиї це прапори, навіть маленькі діти. Їх прийняли давно й прийняли не як гостей, а так, як приймають Бога: просто до серця, відразу, безоглядно й навіки» (Клекіт, 1943:23).

Отже, на західноукраїнських теренах зароджувався і набирав силу державотворчий процес. Активна учасниця тогочасних подій О. Романишин згадувала: «В княжому городі Льва вже кипіла гарячково праця - народ з ентузіазмом почав відновляти та організовувати свої власні адміністративні, господарські та культурні установи, власну міліцію - охорону й безпеку громадян і держави; почав направляти та урухомлювати пошкоджені в часі воєнних дій установи та устаткування, найважливіші засоби для життя міста: воду, світло, харчові крамниці, лікарні, транспорт тощо. Ціле місто потонуло в синьо-жовтих прапорах. Подібно поступало українське населення всюди на звільнених від москалів теренах. Народ почав відбудовувати свою власну державу» (Романишин, 1981:1034). Подібну інформацію знаходимо й у мемуарах Богдана Казанівського: «Населення Львова бачило вперше явну організовану силу ОУН... i хоч не всі були націоналістами або прихильниками ОУН, то кожний український патріот радів Актом 30-го червня і готовий був даром допомагати в адміністрації. Це було видно з того, як до команди зголошувалися різні люди 3 різними фахами й хотіли стати до праці, не питаючи за платню. Це було велике духовне 
піднесення народу, який знав, чого хоче й що має робити для великої справи» (Казанівський, 1975:217 - 218). Навіть К. Паньківський, який критично оцінював організовані бандерівцями Народні Збори, у своїх спогадах, однак, визнавав наступне: «Ми мусили 3 тим рахуватися, що за шумними гаслами ОУН йде велика частина громадянства, а передовсім молоді» (Паньківський, 1957:74).

Державотворча активність була вкрай негативно сприйнята нацистською верхівкою. Львівські події змусили ііі показати справжнє ставлення до українського питання. Наслідком цього стало затримання 5 липня у Кракові і відправлення до Берліна Степана Бандери та його соратників, де вимагали від них визнати недійсним Акт 30 червня. Наступного дня з'явилася відозва ОУН(б). «Закріплюючи на своїх землях українську владу, - наголошувалось у ній, мусимо пам'ятати: війна ще не скінчена! Доки на наших землях зістанеться хоч один москвин, лях чи інший ворог - наїзник, ми боремося дальше... Пам'ятаймо: вся влада в українські руки! До влади дійдемо тільки збройною рукою» (ОУН в 1941 рочі. Ч. 1, 2006:290 - 291).

11 липня окупаційна влада видала розпорядження про заборону не лише маніфестацій на підтримку Акта 30 червня, а й взагалі будь-якої політичної діяльності українських організацій (Украӥна у Другій світовій війні у документах, 1997:166).

Як випливає з німецьких дипломатичних джерел, міністру закордонних справ I. Ріббентропу 21 липня рекомендували дотримуватись позиції, що події 30 червня були «самовільними діями відомої честолюбної й активної групи Бендери» та що «інсценізований нею у Львові Акт не має жодного державно-правового значення» (Украинские националистические организации в годы Второй мировой войныl, 2012:379).

Своєю чергою, політична служба ОУН у німецькій столиці озвучила тоді ж заяву «Щодо становища у Львові». У ній зазначалося, що події 30 червня слід сприймати як «історичний факт», а проголошений Акт, так само, як Акт 22 січня 1918 року у Києві і Акт 1 листопада 1918 року у Львові, «стане символом сучасної визвольної боротьби української нації» (ОУН в 1941 рочзі. Ч. 2, 2006:351). У заяві робився наголос на тому, що «удар по українському уряді буде трактуватися українським народом як ворожий акт німецького райху проти ідеї української державності» (ОУН в 1941 ройі. Ч. 2, 2006:352). 
У зв'язку з цим Петро Дужий зауважив: «Люди побачили, що нові окупанти не кращі за московитих. Акт 30 червня прискорив процес політичного прозріння. I в тому його велике значення» (Дужсий, 1993:28).

У відповідь на вимогу нацистів ліквідувати уряд і припинити державотворчу пропаганду ОУН(б) підготувала меморандум, у якому, зокрема, зазначалося: «Ліквідація теперішнього державного уряду, який постав на українській землі з волі українського народу за відсутності ставлення щодо будівництва Української держави 3 боку Німеччини, могла б вказувати на той факт, що Німеччина не бажає постання Української держави... Ці застереження ми наводимо тому, що питання Акта 30 червня 1941 року має для української політики принципове значення та далекосяжні наслідки... висунена вимога... заперечує ці далекосяжні фактори» (ОУН в 1941 рощі. 4. 2, 2006:439, 443).

Попри німецькі розпорядження не влаштовувати маніфестацій на підтримку Акта і взагалі не займатися політичною діяльністю, бандерівці не припинили його проголошувати в містах і селах. Так, згідно з інформацією, надісланою крайовим провідником Іваном Климів-Легендою С. Бандері, ОУН(б) змогла перебрати владу у 187 з 200 районів Волині, Галичини, Буковини - у 3300 населених пунктах (Відновлення Української держави в 1941 роичі, 2001:180).

15 вересня окупанти повторно заарештували С. Бандеру, Я. Стецька, а також півтори тисячі бандерівців по всій Україні та в еміграції, яких згодом вивезли в концтабір Заксенхаузен, 15 функціонерів Організації були розстріляні, інші інтерновані. «В тому самому менш-більш часі відбулись арешти теж по всіх інших містах Західньої України, - писав П. Мірчук. - Причому Гестапо вжило підступу і зради: підшившись під військове командування, Гестапо запросило представників української влади на місцях на нараду для обговорення справ, що виринали у зв'язку з перебуванням на українській території німецької армії, і коли українські представники прийшли, їх було негайно заарештовано і при вжитті фізичного насильства відставлено до поліційних тюрем у Львові» (Мірчук, 1967:428). За словами колишнього в'язня концтабору в Аушвіці Михайла Марунчака, «погромний наступ на Організацію Українських Націоналістів-Революціонерів у вересні 1941 року започаткував приплив сюди українського політичного елементу, який був призначений на знищення. Це підтвердили дальше фізичні ліквідації українців зимою 1941-42 років в Києві» (Марунчак, 1992:370). 
Дізнавшись про арешти 15 вересня, М. Лебедь скликав того ж дня у Львові, на конспіративній квартирі, нараду керівного складу бандерівської ОУН, якому вдалося залишитися на волі. «Лебедь уже мав короткі інформації про те, як пройшли арешти в різних станицях Львова і ближчих районів, заслухав вістей від присутніх, заповів, що організація переходить вповні до підпілля і починає вести боротьбу проти німецьких окупантів, - згадував іiі учасник Мирослав Прокоп. - Він також повідомив, що на найближчу дату скликає конференцію, про яку повідомить зв'язками...» (Цит. за: Патриляк, 2012:139).

Висновки. Отже, праці і спогади учасників українського визвольного руху воєнної доби свідчать, що підготовлений активом ОУН(б) і проголошений 30 червня 1941 р. у Львові Акт відродження української державності викликав величезний ентузіазм серед українського населення і став початком державотворчих процесів у краї. Проаналізувавши реакцію офіційного Берліна на зазначені події, оунівські лідери усвідомили, що їхній ситуативний союз із гітлерівцями закінчився, а надії на підтримку останніми української справи - ніщо інше, як ілюзії. Відтепер ОУН(б) розпочинає підготовку до відкриття нового фронту - антинімецького. «Уже у вересні 1941 р. гітлерівці розпочали по всій Україні масові арешти членів і прихильників ОУН, - згадував іiі провідний діяч Василь Галаса. - Тим самим німецькі окупанти оголосили війну українському національно-визвольному рухові і всьому народові. Ми відповіли на війну війною. Тепер ОУН стала до боротьби проти двох окупантів - гітлерівської Німеччини та большевицької Росії. Ішлося не про фронтові атаки проти двох загарбників, а про визначення ідейно-політичної платформи визвольного руху щодо цих імперій, армії яких змагалися за панування над Україною. Наша платформа відкидала згубну орієнтацію певних українських кіл на Німеччину або Росію. Практичну боротьбу ми вели тими силами, які змогли на той час організувати, і такими методами, які були доцільні й можливі у кожній конкретній ситуації» (Галаса, 2005:34).

Проголошення Акта 30 червня 1941 р. та безкомпромісне відстоювання його створювало бандерівській ОУН морально-політичну перевагу для того, щоб взяти у свої руки кермо націоналістичного Руху опору. 


\section{Використані посилання}

Андрієвський Д. 1955. Міжнародня акція ОУН. Організаиія українських начіоналістів. 1929-1954. Б.м: На чужині, с. 141-165.

Бандера С. 1948. Слово до Українських НаціоналістівРеволюціонерів за кордоном. На чужині. с. 69.

Відновлення Української держави в 1941 році. Нові документи i матеріали. 2001. К.: Українська видавнича спілка, с. 198.

Галаса В. 2005. Наме життя $і$ боротьба. Спогади. Львів: Видавництво «МС», с. 272.

Дашкевич Я. 2001. Відновлення Української держави 1941 р. Проблеми дослідження. Українське державотворення. Акт 30 червня 1941: Збірник документів і матеріалів. Львів; К.: Літературна агенція «Піраміда», с. XXIV-XLV.

Дідик Г. 1987. До Президії Верховної Ради СРСР. Украӥнський вісник. К.; Львів, Вип. 8. с. 187-192.

Дужий П. 1993. До генези відновлення української державності в 1941 році. Національно-визвольна боротьба 20-50-х років XX ст. в Україні. Збірник матеріалів Першої міжнародної наукової конферениії. Львів, 25-26 червня 1991. К.; Львів, с. 20-29.

Казанівський Б. 1975. Шляхом Легенди: Спомини. Лондон: Українська видавнича спілка, с. 292.

Карпій М. 2004. Дорога на Схід України. За ї̈ волю. Тернопіль: Лілея, с. 86.

Клекіт Г. 1943. Голос крови. Ідея і чин. Ч. 3. с. 21-23.

Котелець-Лісовий С. 1982. Мій спомин з Легіону. У лавах дружсиників: Спогади учасників. Денвер, с. 74-101.

Кук В. 1993. Відновлення Української Держави (До 50-річчя Акту відновлення Української Держави, проголошеного у Львові 30 червня 1941р.). Начіонально-визвольна боротьба 20-50-х років ХХ ст. в Україні. Збірник матеріалів Першої міжнародної наукової конференції. Львів, 25-26 червень 1991. К.; Львів, с. 30-59.

Кук В. 2001. Державотворча діяльність ОУН. Акт відновлення Української держави 30 червня 1941 р. Українське державотворення. Акт 30 червня 1941 р. Збірник документів і матеріалів. Львів; К.: Літературна агенція «Піраміда», с. V-XXIII.

Лебедь М. 1946. УПА. Українська Повстанська Армія. Ї̈̈ генеза, ріст і дії у визвольній боротьбі українського народу за українську самостійну соборну державу. Ч. 1. Німецька окупаиія Украӥни. Видання Пресового Бюра УГВР, с. 127. 
Марунчак М. 1992. На ревірі в Авшвіці й остання вибірка до газу на блоці ч. 19. В боротьбі за Украӥнську Державу. Есеї, спогади, свідчення, літописання, документи Другої світової війни. Львів: Меморіал, с. 369-390.

Мірчук П. 1953. Акт відновлення Української Державности 30 червня 1941 року: (його тенеза та політичне й історичне значення). Друге видання. Мюнхен, с. 64.

Мірчук П. 1967. Гітлерівський наступ на українських самостійників. Ярослав Стецько. 30 червня 1941. Проголошення відновлення державності Украӥни. Торонто: Гомін України, с. 427-431.

ОУН в 1941 році. Документи. В 2-х ч. Ч. 1. 2006. К.: Інститут історії України НАНУ, с. 336.

ОУН в 1941 році. Документи. В 2-х ч. Ч. 2. 2006. К.: Інститут історії України НАНУ, с. 337-616.

Паньківський К. 1957. Від держави до Комітету. Нью-Йорк; Торонто, с. 160.

Патриляк I. 2012. «Встань $і$ борись! Слухай і вір...»: українське націоналістичне підпілля та повстанський рух (1939-1960рр.). Львів: Часопис, с. 592.

Романишин О. 1981. В 40-ву річницю Акту. Визвольний шлях. Суспільно-політичний $i$ науково-літературний місячник. Кн. 8. c. $1032-1037$.

Савчин М. 2003. Тисяча доріг. Спогади жінки-учасниці підпільновизвольної боротьби під час $і$ після Другої світової війни. К.: Смолоскип, с. 546.

Степовий Ю. 1947. Син Закарпаття (українське револючійне підпілля в Києві) 1941-1942 р. Мюнхен: Вид-во ім. Хвильового, с. 34.

Стецько Я. 1967. 30 червня 1941. Проголошення відновлення державності Украӥни. Торонто: Гомін України, с. 13-326.

Туди, де бій за волю (спогади курінного УПА Максима Скорупського-Макса). 1992. К.: Вид-во ім. О. Теліги, с. 351.

Україна у Другій світовій війні у документах. Збірник німещьких архівних матеріалів. Т. 1. 1997. Львів, с. 384.

Украинские наџионалистические организации в годы Второй Мировой войны. Документы: В 2-х т. Т. 1: 1939-1943. 2012. М.: Российская политическая энциклопедия (РОССПЭН), с. 817. 


\section{REFERENCES}

Andriyevs'kyi D. 1955. OUN International Action. Organization of Ukrainian nationalists. 1929-1954. Na chuzhyni, pp. 141-165 (ukr).

Bandera S. 1948. The Word to Ukrainian Nationalist Revolutionaries Abroad. Na chuzhyni, p. 69 (ukr).

Restoration of the Ukrainian state in 1941. New documents and materials. 2001. Kyiv: Ukrainian Editorial Association, p. 198 (ukr).

Galasa V. Our life and struggle. Memoirs. 2005. Lviv: Editorial office "MS", p. 272 (ukr).

Dashkevych Ya. 2001.Restoration of the Ukrainian state in 1941. Problems of research. Ukrainian state building. Act 30 June 1941: Collection of documents and materials. Lviv; Kyiv: Literary agency „Piramida”, pp. XXIV-XLV (ukr).

Didyk G. 1987. To the Presidium of the Supreme Soviet of the USSR. Ukrainian Herald. Kyiv; Lviv, N. 8. pp. 187-192 (ukr).

Duzhyi P. 1993. By the genesis of the restoration of Ukrainian statehood in 1941. National liberation struggle 20-50s of the twentieth century in Ukraine. Collection of Materials of the First International Scientific Conference. Lviv, 25-26 June 1991. Kyiv; Lviv, pp. 20-29 (ukr).

Kazanivs'kyi B. 1975. Through the Legend: Memorial. London: Ukrainian Editorial Association, p. 292 (ukr).

Karpiy M. 2004. Road to the East of Ukraine. For her will. Ternopil’: Lileya, p. 86 (ukr).

Klekit G. 1943. Blood voice. The idea and the work. N. 3. pp. 21-23 (ukr).

Kotelec'-Lisovyi S. 1982. My remembrance of the Legion. In the ranks of the warriors: memories of the participants. Denver, pp. 74-101 (ukr).

Kuk V. 1993. Restoration of the Ukrainian State (To the 50th anniversary of the Act of Recovery of the Ukrainian State, proclaimed in Lviv on June 30, 1941). National liberation struggle 20-50s of the twentieth century. in Ukraine. Collection of Materials of the First International Scientific Conference. Lviv, 25-26 June 1991. Kyiv; Lviv, pp. 30-59 (ukr).

Kuk V. 2001. State-building activity of the OUN. Act of restoration of the Ukrainian state on June 30, 1941. Ukrainian state building. Act of June 30, 1941. Collection of documents and materials. Lviv; Kyiv: Literary agency „Piramida”, pp. V-XXIII (ukr). 
Lebed' M. 1946. UPA. Ukrainian Insurgent Army. Her genesis, growth and actions in the liberation struggle of the Ukrainian people for the Ukrainian independent congregation state. Part 1 German occupation of Ukraine. Edition of the Press Bureau of the Ukrainian Main Liberation Board, p. 127 (ukr).

Marunchak M. 1992. On the revue in Auschwitz and the last assortment for gas at block 19. In the struggle for the Ukrainian state. Essays, memoirs, testimonies, chronicles, documents of the Second World War. Lviv: Memorial, pp. 369-390 (ukr).

Mirchuk P. 1953. Act of restoration of Ukrainian State on June 30, 1941: (his genesis and political and historical significance). Second edition Munich, p. 64 (ukr).

Mirchuk P. 1967. Hitler's offensive against Ukrainian settlers. Yaroslav Stetsko June 30, 1941. Proclamation of the restoration of statehood of Ukraine. Toronto: Gomin Ukrayiny, pp. 427-431 (ukr).

OUN in 1941. Documents in 2 parts. Part 1. 2006. Kyiv: Institute of the History of Ukraine, p. 336 (ukr).

OUN in 1941. Documents in 2 parts. Part 2. 2006. Kyiv: Institute of the History of Ukraine, pp. 337-616 (ukr).

Pan'kivs'kyi K. 1957. From State to Committee. New-York; Toronto, p. 160 (ukr).

Patrylyak I. 2012. "Rise and fight! Listen and Believe... ": Ukrainian Nationalist Underground and Rebel Movement (1939-1960). Lviv: Chasopys, p. 592 (ukr).

Romanyshyn O. 1981. In the 40th anniversary of the Act. Liberation path Social-political and scientific literary monthly magazine. Book 8 . pp. 1032-1037 (ukr).

Savchyn M. 2003. A thousand roads. Memoirs of women participating in the underground liberation struggle during and after the Second World War. Kyiv: Smoloskyp, p. 546 (ukr).

Stepovyi Yu. 1947. Son of Transcarpathia (Ukrainian Revolutionary Underground in Kyiv) 1941-1942. Munich: Khvylovyi Editorial office, p. 34 (ukr).

Stetsko Ya. 1967. June 30, 1941. Proclamation of the restoration of statehood of Ukraine. Toronto: Gomin Ukrayiny, pp. 13-326 (ukr).

There, where the fight for freedom (the memoirs of the kuriinyi UPA Maxim Skorupsky-Max). 1992. Kyiv: Olena Teliha Editorial office, p. 351 (ukr).

Ukraine in the Second World War in documents. Collection of German archival materials. Vol. 1. 1997. Lviv, p. 384 (ukr). 
Ukrainian nationalist organizations during the Second World War. Documents: In 2 volumes. Vol. 1: 1939-1943. 2012. Moscow: ROSSPEN, p. 817 (rus).

\section{Trofymovych V., Trofymovych L. DISCLOSURE OF THE ACT OF 30 JUNE 1941 IN THE HISTORICAL WORKS AND MEMORIES OF PARTICIPANTS OF THE UKRAINIAN LIBERATION MOVEMENT}

Due to the source of study analysis and synthesis, the authors found out the materials in the historical works and memoirs of the participants in Ukrainian liberation movement. The following materials are connected with the Act of June 30, 1941 about the restoration of the Ukrainian state. They are reviewed and compared with other sources, including the importance of these sources, the authors subjective opinions, the influence of the social-politic situation on their writings, political and party affiliations, the possibility of wrong coverage of the events and the limit of human memory ability.

Through the prism of historical works and memoirs, the current activity of The Organization of Ukrainian Nationalists was explained in the article. It was guided by the principle of relying on its own forces in its struggling for the Ukrainian statehood, and at the same time, to gain strong support of the external factors. After working out these sources we can conclude that the leaders of the OUN until July 1941 had mostly abstract, general and controversial ideas of the real Nazis intentions towards Ukraine.

Historical works and memories of the participants of the Ukrainian liberation movement during the war period indicated that: The Act of restoration of the Ukrainian state was prepared by the leaders of Bandera 's OUN, proclaimed on June 30, 1941 in Lviv, and caused great enthusiasm among the Ukrainians and became the beginning of statebuilding processes in Western Ukraine. After analyzing the reaction of Berlin to these events, the banderites realized that their alliance with the Nazis was broken. Since then, Bandera 's OUN had begun their preparations for the opening of a new front against German.

Keywords: The Act 30 June 1941, Ukrainian nationality renewal, OUN(b), Germans, works, memoirs. 